\title{
Performance and Aging of Microtubular YSZ-based Solid Oxide Regenerative Fuel Cells ${ }^{\times}$
}

\author{
M. A. Laguna-Bercero ${ }^{1,2}$, R. Campana ${ }^{1}$, A. Larrea ${ }^{1}$, J. A. Kilner ${ }^{2}$ and V. M. \\ Orera $^{1}$
}
${ }^{1}$ Instituto de Ciencia de Materiales de Aragón, ICMA, CSIC - Universidad de Zaragoza, Pedro Cerbuna 12, 50009 Zaragoza, Spain
${ }^{2}$ Department of Materials, Imperial College London, SW7 2AZ London, UK

\section{Received}

\section{[*] Corresponding author, malaguna@unizar.es}

\begin{abstract}
Fuel electrode supported microtubular solid oxide fuel cells (SOFC) fabricated at ICMA have been characterized in both solid oxide steam electrolyser (SOEC) and fuel cell modes. The cells consists of a fuel electrode supporting tube of Ni/YSZ with $40 \%$ porosity, $400 \mu \mathrm{m}$ thickness, $2.4 \mathrm{~mm}$ diameter and 100-150 mm length, a $15 \mu \mathrm{m}$ thick YSZ electrolyte and a 50vol\% LSM/YSZ composite air electrode of $20 \mu \mathrm{m}$ thickness and LSM/YSZ (80/20 vol\%) up to $2 \mathrm{~cm}^{2}$ area as current collector in the air side. Platinum paste and wires were used as interconnectors in the air chamber and $\mathrm{Ni}$ felt in the fuel side. SOFC and SOEC experiments were performed at temperatures between 750 and $950{ }^{\circ} \mathrm{C}$ using synthetic air in the oxygen electrode and different partial pressures of steam in the fuel side. Analysis of the polarization contributions to the $j$ - $\mathrm{V}$ curve in $\mathrm{FC}$ operation mode was performed using theoretical models, as discussed in the text. The effect of the steam concentration and temperature on the electrolysis and fuel cell experiments is presented and discussed. The cells are reversible in both modes of operation at low fuel conversion rates. According with previous observations, when cells are operated at high steam conversion rates the cell voltage tends to saturate. Irreversible damage was observed by SEM at the YSZoxygen electrode interface after operation, probably due to the electrolyte reduction produced at high voltages.
\end{abstract}

Keywords: microtubular, zirconia, SOFC, SOEC, hydrogen production

\section{Introduction}

Hydrogen is probably the preferred energy carrier for a future zero-carbon economy but several research efforts are required in order to supply inexpensive and plentiful amounts of fuel. Water electrolysis is probably the cleanest method to produce hydrogen and in this field, High Temperature Electrolysers (HTE) present several advantages in comparison with the commercial proton-exchange or alkaline electrolysers, proven technologies that can achieve energy efficiencies of about $75 \%$ [1]. Increasing the operation temperature of the electrolyser, the electrical energy demand is significantly reduced, as part of this electricity is supplied as heat. The high temperatures required for SOEC operation lead to a lower theoretical decomposition temperature for steam and lower electrode polarization losses compared to those associated with liquid water. Solid oxide cells operate at high temperature with high fuel to electricity conversion ratios and they are good candidates for high temperature electrolysis. One of

\footnotetext{
×Article is part of "Special issue Albacete 2009"
} 
the first works on SOEC was that of Dönitz and Erdle who reported on the operation of YSZ electrolyte cells with current densities of $0.3 \mathrm{~A} \mathrm{~cm}^{-2}$ and $100 \%$ Faraday efficiency at only $1.07 \mathrm{~V} \mathrm{[2].} \mathrm{Another}$ advantage of SOECs is that they can operate reversibly as solid oxide fuel cells (SOFC) producing electricity with high efficiency by consuming the stored hydrogen. Where a cell is capable of being used as both fuel cell and as an electrolyser cell it is referred to as a solid oxide regenerative fuel cell (SORFC). Other applications apart from water electrolysis include $\mathrm{CO}_{2}$ electrolysis, co-electrolysis of steam and $\mathrm{CO}_{2}$, or natural gas-assisted electrolysis [3,4,5,6]. The state of the art in SOEC for YSZ based cells using Ni-YSZ as the hydrogen electrode and LSM (or LSM-YSZ) as the oxygen electrode has been relatively active in the last decade. Different authors have found ASR values at OCV of around 0.7 at $1000{ }^{\circ} \mathrm{C}$ [7], 1.8 at $900{ }^{\circ} \mathrm{C}$ [8], 1.25 at $700{ }^{\circ} \mathrm{C}$ [9], 0.6 at $920{ }^{\circ} \mathrm{C}$ [10] and best results up to date were reported by Hauch et al. that found 0.27 at $850^{\circ} \mathrm{C}[11]$.

Development of the oxygen electrode is one of the major problems in SOFC, due to polarization losses at the temperatures under operation [12]. Several works in the literature are now focused on improving oxygen electrodes for SOEC applications $[9,13,14,15]$, but up to date lower polarization resistances are still obtained using the standard LSM/YSZ oxygen electrode [16]. Recently, oxygenexcess phase materials, such as the $\mathrm{Nd}_{2} \mathrm{NiO}_{4+\delta}$ has been proposed as a good candidate especially in SOEC mode [17], where there are high oxygen partial pressures at the oxygen electrode interface.

Micro-tubular SOFCs have attracted great interest in the recent years $[18,19,20]$. Advantages of micro-tubular SOFCs include increased power density per unit volume, shorter times to start-up and shutdown (rapid thermal cycling), easy sealing and less redox cycling damage. For example, when the tubes are $<3 \mathrm{~mm}$ in diameter, it is shown that the power density and thermal shock resistance are much increased, with start-up in a few seconds rather than hours for planar designs, as demonstrated by Kendall [21]. For similar Ni/YSZ-supported and YSZ based cells, best results found in the literature were power densities of around $500 \mathrm{mWcm}^{-2}$ [22], $550 \mathrm{mAcm}^{-2}$ [23], $800 \mathrm{mWcm}^{-2}$ [24], and $1160 \mathrm{mWcm}^{-2}$ [25], all of them measured at $850^{\circ} \mathrm{C}$ and $0.7 \mathrm{~V}$.

We have also recently demonstrated that a fuel electrode supported Ni/YSZ-YSZ-LSM microtubular cell present high electrochemical efficiency in SOEC mode. At $850^{\circ} \mathrm{C}$ we measured current densities of -1 $\mathrm{A} \mathrm{cm}^{-2}$ at $1.3 \mathrm{~V}$ with steam utilisation, measured by mass spectrometry in the close gas circuit set-up close to $100 \%$ Faraday efficiency [26]. That corresponds to the thermal neutral voltage in which heat generated by cell equals that needed for reduction of water [27]. However, in terms of hydrogen production efficiency in some cases it should be of interest to increase the current density to achieve a greater hydrogen production rate per electrolyser volume. A strong tendency to voltage saturation at high current densities values was observed similar to that reported by Schefold et al. [28] in planar cells at high fuel conversion factors. This behaviour has been associated to the increase in the electronic conductivity of the electrolyte due to YSZ reduction. Although the cell withstood current densities up to $-6 \mathrm{~A} \mathrm{~cm}^{-2}$ its performance deteriorates after several hours of operation at these high current densities [26].

In the present work we have intend to understand these cell deterioration effects using a microtubular cell with a bilayer oxygen electrode (functional layer and current collector layer) as a test cell. Results in SOFC and SOEC mode as a function of the temperature and steam concentration, as well as post mortem microstructure cell observations are discussed.

\section{Experimental}

Nickel/yttria-stabilized-zirconia (Ni/YSZ) supported microtubular cells were used in this study. NiO (Alfa-Aesar) and 8YSZ (Tosoh) were used to produce the microtube support precursors. Prior to the tube fabrication process, $\mathrm{NiO}$ was ball-milled in 2-propanol and then mixed with YSZ and pore formers in acetone. Then, NiO/YSZ tubes were fabricated by cold isostatic pressing (CIP) at $200 \mathrm{MPa}$. YSZ gastight electrolyte was then deposited by wet powder spraying (WPS) using 2-propanol as liquid vehicle. $\mathrm{NiO} / Y S Z$ electrode-YSZ electrolyte was co-sintered at $1400{ }^{\circ} \mathrm{C}$ for 2 hours. The dimensions of the tubes after sintering are around 10-15 cm length and $2.4 \mathrm{~mm}$ inner diameter. LSM (Fuelcell Materials) was used for the oxygen electrode. A-site deficient manganite $\left(\left(\mathrm{La}_{0.8} \mathrm{Sr}_{0.2}\right)_{0.98} \mathrm{MnO}_{3}\right) /$ yttria-stabilized zirconia (LSM/YSZ) (50/50 wt\%) functional layer composite and $(80 / 20 \mathrm{wt} \%)$ current collector layer were deposited by dip-coating and sintered at $1150{ }^{\circ} \mathrm{C}$ during 1.5 hours each step, respectively. Optimum gas and electronic transport, and also good thermomechanical stability was obtained by adjusting the composition of the powders and the fabrication procedure and described in reference [29].Steam was supplied to the fuel electrode site by the use of a gas bubbler in water surrounded by a thermostatic bath maintained at a constant temperature for the required amount of steam with the steam content measured 


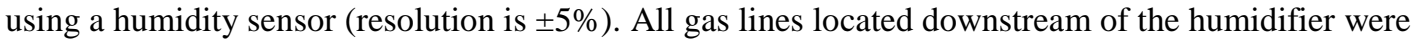
externally heated in order to prevent steam condensation. Porosity of the oxygen electrode layers was measured by image analysis using Digital Micrograph (Gatan) software and also confirmed by $\mathrm{Hg}$ porosimetry, in LSM/YSZ pellets sintered using the same conditions, with a Micromeritics Autopore II 9215 porosimeter.

Pt wires were used for the current injection and potential probe, and Ni foam (for the Ni/YSZ electrode) and Pt paste (for the LSM/YSZ electrode) were used as current collectors. The active area used for the experiments was up to $\sim 2 \mathrm{~cm}^{2}$. Details for the microtubular configuration setup and also for the FCelectrolysis system can be found in the following references $[26,30]$. Nickel oxide was reduced to metallic nickel during the heatig-up process at $820^{\circ} \mathrm{C}$ under pure hydrogen saturated with deionized water at room temperature $\left(\sim 3 \% \mathrm{H}_{2} \mathrm{O}\right)$. The cell was tested ( $j$-V curves) in SOFC mode with $120 \mathrm{ml} / \mathrm{min}$ of $3 \%$ humidified pure $\mathrm{H}_{2}$ as fuel and syntetic air in the oxygen electrode side.

Two sets of current density-voltage $(j-\mathrm{V})$ experiments in both SOFC- and SOEC mode were performed at cell temperatures of $750,820,895$ and $950{ }^{\circ} \mathrm{C}$ using different steam compositions in the inner side (Ni/YSZ). First set of experiments were run using $120 \mathrm{ml} / \mathrm{min}$ humidified pure Hydrogen. Second set was performed with a gas containing $50 \% \mathrm{H}_{2} \mathrm{O}$ (gas flows were $\mathrm{Q}_{\text {total }}=100$ $\mathrm{ml} / \mathrm{min}$ : $50 \mathrm{ml} / \mathrm{min} \mathrm{H}_{2} \mathrm{O}, 40 \mathrm{ml} / \mathrm{min}_{2}$ and $10 \mathrm{ml} / \mathrm{min}_{2}$ ). Finally, last set was performed with $25 \% \mathrm{H}_{2} \mathrm{O}$ $\left(\mathrm{Q}_{\text {total }}=100 \mathrm{ml} / \mathrm{min}: 25 \mathrm{ml} / \mathrm{min} \mathrm{H}_{2} \mathrm{O}, 60 \mathrm{ml} / \mathrm{min} \mathrm{N}_{2}\right.$ and $\left.15 \mathrm{ml} / \mathrm{min}_{2}\right)$. Synthetic air $\left(p\left(\mathrm{O}_{2}\right)=0.21 \mathrm{~atm}\right)$ was always used for the oxygen electrode side. Galvanostatic and galvanodynamic experiments were performed using an Autolab PGSTAT30 equipment. A complete cycle of increasing-decreasing voltagecurrent in both operation modes at an scan rate of $2.5 \mathrm{~mA} \mathrm{~cm}^{-2} \mathrm{~s}^{-1}$ took about 1 hour. All the scan directions of the $j-\mathrm{V}$ curves presented in the text start from OCV. Prior to the electrolysis experiments, we applied a fixed current through the cell assuring that $j$-V behaviour is stabilized to a stationary state. AC impedance spectroscopy was also performed using an Autolab PGSTAT30 fitted with a frequency response analyser (FRA) (Autolab, EcoChemie, Netherlands). Impedance measurements under different potential loads were performed in potentiostatic mode using a sinusoidal signal amplitude of $100 \mathrm{mV}$ over the frequency range of $10 \mathrm{kHz}$ to $0.1 \mathrm{~Hz}$. However, unfeasibility of introducing a reference electrode along with the large broadening of the relaxation peaks due to inhomogeneities in the cell components makes it difficult to separate the different processes in this cell. For these reasons EIS was only employed to obtain the ohmic impedance contribution to the total resistance of the cell. A set of experiments, $j$-V curves plus EIS analysis took a full day for each steam concentration.

Scanning electron microscopy (SEM) experiments were performed on polished samples in a Quanta Field Emission Gun SEM.

\section{Results and Discussion}

\subsection{Microstructural characterization}

In figure 1 we present a typical cross-section for the microtubular Ni/YSZ-YSZ-LSM/YSZ cell. Note the "tree-root-like" Ni/YSZ-YSZ interface and the phase distribution in the double oxygen electrode layer. Detailed information of the fabrication process, microstructure, porosity, tortuosity and gas permeability for the Ni/YSZ-YSZ half cell can be found in Refs. [29] and [31]. In the present paper we used an oxygen electrode dual layer consisting of an active functional layer (LSM/YSZ) (50/50 wt \%) and a current collector layer (80/20 wt \%). In table 1 we summarize the results of porosity as well as the average pore diameter for both electrodes. If we observe the results stated in this table, for the Ni/YSZ electrode both analysis (SEM and $\mathrm{Hg}$ porosimetry) were performed using the same samples. The agreement obtained by both methods indicates that both procedures are correct. However, for the $\mathrm{LSM} / \mathrm{YSZ}$ composite, it is not possible to perform $\mathrm{Hg}$ porosimetry in situ, as the thickness of the electrode is very thin. Then, we either have to rely on the SEM analysis, where we do not distinguish between open and close porosity, or we have to perform bulk samples (pellets) of the same composition as the layers deposited by dip-coating, and perform $\mathrm{Hg}$ porosimetry of those pellets. The total porosity for the dip-coated layer, analysed by SEM micrographs, was $37.1 \%$ and $40 \%$ for the functional (LSM50) and the current collector layer (LSM80), respectively. However, for the LSM/YSZ pellets, the porosity measured by image analysis was $27.3 \%$ and $28.1 \%$ for the LSM50 and the LSM80 respectively. This is consistent with the $\mathrm{Hg}$ porosimetry measurements performed on those pellets, where we measured an open porosity of $28.7 \%$ and $31.3 \%$ for the LSM50 and the LSM80 electrode, respectively. Those results indicate that the porosity of the pellets is lower than the one in our layers and we can then conclude that the total porosity for our oxygen electrode layer is around $37-40 \%$ for both functional and current collector layers. 


\subsection{Electrical characterization}

\subsubsection{Simulation of the current density-voltage ( $\mathbf{j}-\mathrm{V})$ curves}

The cell was firstly tested in SOFC mode. Current density-voltage $(j-\mathrm{V})$ in SOFC mode measured at $950{ }^{\circ} \mathrm{C}$ with $120 \mathrm{ml} / \mathrm{min}$ humidified pure hydrogen supplied to the fuel electrode is presented in figure 2. Experiments were carried out down to $0.6 \mathrm{~V}, 600 \mathrm{~mW} \mathrm{~cm}^{-2}$ which correspond to a negligible $7 \%$ fuel utilisation to avoid cell deterioration. The cell was also run in SOEC mode and the $j$-V curve is also given in Fig. 2. The curve has been recorded up to $-0.4 \mathrm{~A} \mathrm{~cm}^{-2}(1.55 \mathrm{~V})$ at the current rate as indicated in the experimental section. No hysteretic behaviour was detected, as also reported in our previous experiments [26]. It can be observed from the graph that for this fuel composition, the cell departs from an ideal reversible behaviour since it performs well in FC mode but relatively poor in SOE mode. In the FC mode the $j$-V curve presents a typical slightly concave shape at low current densities and convex at high current densities. In SOEC mode the slope of the curve increases monotonically with $j$ up to values around 1.45 $\mathrm{V}$ where an abrupt increase of voltage is observed. Similar slope changes were previously observed in other SOECs at voltages above $1.4 \mathrm{~V}[26,28,32]$.

Analysis of the polarization contributions to the $j$-V curve in $\mathrm{FC}$ mode operation was performed using the model given by Kim et al. [33] for fuel electrode supported YSZ-based cells. For the anode and cathode concentration polarization resistance in this model, it has been assumed that the SOFC cathode (oxygen electrode) limiting current $i_{c s}$ is much larger than the SOFC anode (fuel electrode) limiting current $i_{\text {as }}$. A Tafel equation was taken to account activation polarization.

The model predicts a simple V(j) vs. j relationship

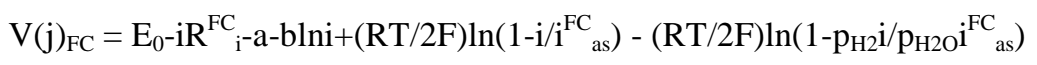

The experimental $j$-V data can be fitted to eq. 1 using four parameters, the resistance $R_{\mathrm{i}}$ which includes ionic electrolyte resistance as well as other ohmic contributions from electrodes and current collectors and interfaces, limiting fuel electrode current $\mathrm{i}_{\mathrm{as}} . E_{0}$ is the Nernst potential which depends on temperature and gas partial pressures.

Best fit of eq. (1) is also given in fig. 2 using the parameters listed in Table 2 . In that case $\mathrm{R}^{\mathrm{FC}}$ can be accurately determined by the slope of the curve, $a$ and $b$ approximately reproduce both the small OCV polarization onset and curvature at low current densities, and $\mathrm{i}^{\mathrm{FC}}$ as from the incipient convexity of curve towards limiting current densities at high current densities values.

More complex is the analysis of the $j$-V curve in SOEC mode. Recently, a general theoretical relationship between cell voltage and current density of a unitised regenerative fuel cell (URFC) based on PEMFCs has been developed as a modification of the Buttler-Volmer equation. With this relationship a computer model has been constructed, which permits fitting the experimental data to obtain saturation current densities values, as well as exchange current densities and charge transfer coefficients [34].

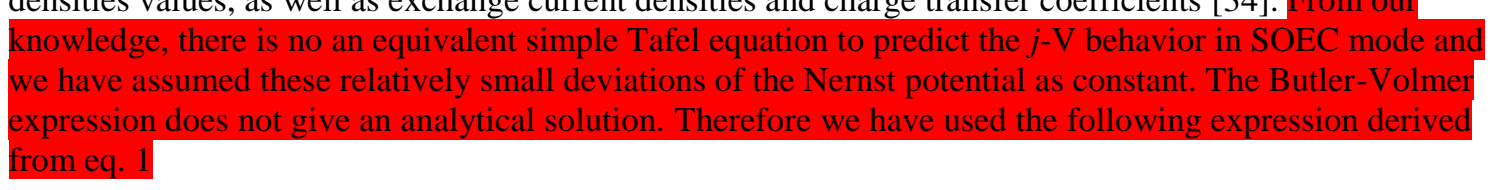

$V(j)_{S O E}=E_{0}+i R^{S O E}{ }^{-a}+(R T / 2 F) \ln \left(1-i / i^{S O E}{ }_{a s}\right)$

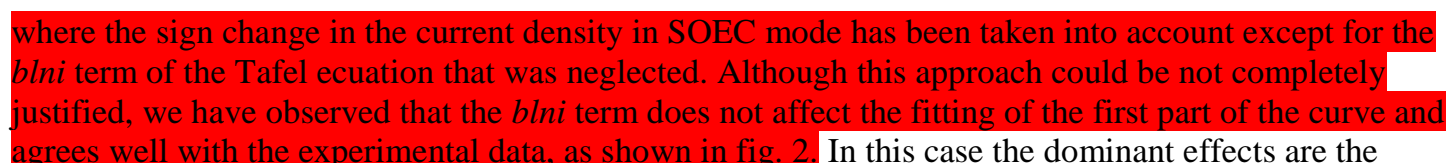

increase in ohmic resistance and the saturation density current. The fitting values can be also found in Table 2.The OCV values are around $50 \mathrm{mV}$ less than those expected from the Nernst equation assuring that there was not significant gas leakage within the cell and on the experimental setup. However, small deviations from Nernst potential are of the magnitude of a making an exact determination of this parameter, and so of the exchange current density and exchange constant rather uncertain. In SOFC mode, total resistance values are slightly higher than those around $0.1 \Omega \mathrm{cm}^{2}$ for best planar SOFCs at this temperature but also similar to those of other microtubular and SOEC cells [35]. For example, saturation current has also been inaccurately determined since we did not operate the cell up to high current densities values. The fitting value of $2 \mathrm{~A} \mathrm{~cm}^{-2}$ is about twice smaller than typical SOFCs [35]. For SOEC operation, most striking feature is the very low value of the limiting current and increase in ohmic resistance. Both effects can be related with the low steam concentration which produces a clear gas 
diffusion limitation. The increase in the $R_{\mathrm{i}}$ as obtained from the $j$-V curve when the humidity decreases has also been recently reported in other SOEC experiments. This is a clear indication that important contributions to the $R_{\mathrm{i}}$ values come from the electrode reactions $[28,35]$. Note that for the used steam concentration, a current density of $0.4 \mathrm{~A} \mathrm{~cm}^{-2}$ corresponds in this case to an steam-to-hydrogen conversion rate of around $85 \%$.

\subsubsection{Effect of the steam concentration in fuel cell mode}

In figure 3 we present $j$-V curves at absolute humidities (AH) of 50\%, 25\% and $3 \%$ measured using the fuel composition given in the experimental section. As expected, higher current densities were obtained for higher hydrogen flows. It is also noticeable that reasonable power densities were obtained at $25 \%$ and $50 \%$ of steam content, where the hydrogen fuel utilization increases in comparison with the one using $3 \%$ of steam content, as observed in table 3 . In this table we can also observe the $R_{\mathrm{i}}$ values $(\approx \mathrm{ASR}$ fuel conversion uncorrected values) calculated from the slope of the $j$-V curves at $750{ }^{\circ} \mathrm{C}$. We obtained similar values for the different fuel compositions. If we carefully analyse the experimental data in figure 3 , we can observe a small polarization contribution, less noticeable for the experiment using $50 \%$ of steam, which corresponds to the polarization due to the gas diffusion the last term of eq. (1).

\subsubsection{Effect of the steam concentration in SOEC mode}

Next, we increased the humidity and studied the cell performance at different temperatures in both FC and SOEC modes. In figure 4 we present $j$ - $\mathrm{V}$ curves as a function of the temperature using $\mathrm{AH}=50 \%$ (fig 4a) and $25 \%$ (fig. 4b). From those graphs we can clearly observe a similar S-shape behaviour as this previously observed for $\mathrm{AH}=3 \%$ and those described in ref. [26]. Since the FC behaviour is similar to that of previous experiments in the following we will focus on the performance in SOEC and in particular in the dependence of total resistance with temperature and steam concentration. The $j$ - $\mathrm{V}$ curves show a concave shape with the slope slightly increasing with current densities up to different voltage values where we observe that there is a tendency to saturation of the cell voltage. This effect happens at high current densities in electrolysis mode and at voltages between 2.2 and $1.8 \mathrm{~V}$ decreasing with the operation temperature. The resistance values $R_{\mathrm{i}}^{\mathrm{SOE}}$ obtained from the slopes of the initial linear part of electrolysis $j$ $\mathrm{V}$ curves are given in Table 4 . It was not possible to get an accurate fitting using eq. 2 as values of $\mathrm{i}_{\text {as }}$ cannot be accurately obtained since a non clear fuel exhaust region is observed in the curves when operating at high steam concentration values. These fuel conversion uncorrected ASR values are a little higher than those obtained by Hauch et al. [11] in planar SOECs but better than other previous SOEC experiments as collected in Table IV of that review of Hauch et al.

EIS was also recorded prior to each electrolysis measurement (OCV experiments). The ohmic resistances given in table 4 were obtained from the intersection at high frequency with Real $(Z)$ axis of the Nyquist plot. Comparison between $R_{\mathrm{i}}$ and $R_{\mathrm{ohm}}$ indicates that there is a strong non ohmic contribution to the total cell resistance. This $R_{\mathrm{i}}-R_{\mathrm{ohm}}$, contribution decreases with an increase of the operation temperature and also increasing the steam concentration and consequently, this is assigned to electrode activation, presumably to changes in the kinetic processes at the fuel electrode. The other important factor is the dramatic decrease in the total resistance at high voltage values.

Schefold et al. [28] also reported a similar effect and interpreted it as the presence of electronic conduction in the thin YSZ electrolyte. Electronic conduction was caused by reduction of the YSZ in the presence of the low oxygen partial pressures of the hydrogen side. Here the effect appears at voltages lower than the YSZ reduction potential of about 2.3 V [36]. YSZ electro-reduction is a well known effect and in YSZ single crystals the electroreduction is accompanied by a dark blue coloured YSZ region moving into the transparent YSZ zone from the oxygen electrode to the fuel electrode [37] with the reduction time. Black yttria stabilised zirconia has been traditionally associated to the presence of electron defects either of extrinsic, $\mathrm{Ti}^{3+}$ [38], or intrinsic, F-centers (oxygen vacancy with two electrons), or even to electrons trapped in $\mathrm{Zr}^{3+}$ [39]. When the concentration of the electron traps is high enough YSZ becomes mixed ionic and electronic conductor (MIEC) [40]. An important aspect is that at low levels of electroreduction this process is reversible, and just decreasing the potential or increasing the oxygen potential, the material returns at its original state of a good ionic conductor. However, for severe electroreduction levels, the concentration of produced oxygen vacancies is high enough to coalesce into metallic zirconium particles which cannot be dissolved again by low temperature processes. In that case, the mixed conduction of YSZ will persist during all the operation cycle.

This observed behaviour is nearly reversible and after each SOEC run we always recover the initial OCV value. Absence of evidence for electrolyte electronic losses makes us think that the first hypothesis holds 
in SOECs. The reversible electroreduction of YSZ is due to production of point defects, more likely electron traps and oxygen vacances rather than to the production of zirconium metallic particles. Next we discuss the possible effects of YSZ reduction on the cell performance in SOE mode. The existence of electronic conduction in the electrolyte cannot explain some of the experimental findings. For example, it does not account that the faradaic water reduction efficiency remains nearly $100 \%$ in the high current density region where the $j$-V curve flattens. That was recently established in SOEC experiments using tubular cells were the output gas concentration was independently measured by mass spectrometry [26]. In addition, in the same work we also observed that after flattening the slope increases again when the fuel conversion rate increases. This cannot be explained if the electrolyte has been already short-circuited. If the YSZ becomes electronic conductor, there will be an extra contribution to the cell which is not balanced by the $\mathrm{H}_{2}$ production, as we have confirmed by mass spectrometry. By this measurement, we have proven that faradaic efficiency is close to $100 \%$, and the apparent change of the impedance should not be caused by the electronic effect of the electrolyte.

We believe that other contributions besides the mere electronic conduction effect have to be added into the discussion. When the YSZ is reduced the situation is similar to the case of MIEC electrolytes such as ceria based electrolytes. Then, two main effects may occur. Firstly, conversion of YSZ particles at the hydrogen electrode from pure ionic conductor into a MIEC-type conductor may increase the catalytic performance for water decomposition of the electrode as it was observed by Uchida el al. [41] in steam cells with ceria-Ni fuel electrode. Furthermore, it is well known from studies in electrolyte systems prone to suffer reduction processes and to become mixed conductors, as the case of ceria electrolytes that reduction starts in the low oxygen pressure electrode and proceeds towards the oxygen electrode. In the oxygen electrode -electrolyte interface, the oxygen chemical potential inside the electrolyte has a propensity to equal the external oxygen potential thus dropping oxygen electrode overpotential [42]. In addition, a thin insulating layer remains near to the oxygen electrode where large potential gradients accumulate $[43,44]$.

Although, the behaviour of the cells is almost reversible, there is evidence of some damage during the operation cycles. In fact, an increase in ohmic and total cell resistance with increasing number of operation cycles was clearly observed, as stated in table 3 . In addition, this degradation has been also observed in successive $j$-V galvanodynamic experiments under the same gas composition, especially at high steam concentrations.

\subsection{Microstructural analysis after operation}

We performed post-mortem microstructure observations of the electrode electrolyte interfaces using SEM experiments. We observed that in addition to a detachment of the LSM/YSZ bilayer from electrolyte, a clear degradation of YSZ near to the air electrode side occurs (fig. 5).

Electrolyte damage can be in agreement of the hypotheses previously formulated. Reversible YSZ electroreduction increases electrode kinetics in the hydrogen side interface which lowers the cathodic polarization losses. An important consequence for this should be that operating in that part of the SOEC curve is about the best situation in terms of hydrogen production efficiency and production rate. However, electrolyte reduction may produce severe undesired and irreversible damage in the electrolyte near to the LSM interface. Different experiments are underway in order to fully corroborate these entire hypotheses. Determination of faradaic water reduction efficiency along the $j$-V curve is critical to assess that point. Microtubular cells provide a simple way to separate the chamber outgases without unwanted reflow or other deleterious effects occurring in other geometries. We are also performing a detailed characterisation of the damaged electrolyte in order to ascertain for the microscopic origin of the damage.

\section{Summary}

Ni/YSZ-YSZ-LSM/YSZ fuel electrode supported microtubular solid oxide fuel cells (SOFC) were characterized in both electrolysis and fuel cell modes. Experimental data was fitted in SOFC mode using a modified Buttler-Volmer equation. At high current densities in SOEC mode, the $j$-V curves tend to saturate the voltage at values between 2.2 and $1.8 \mathrm{~V}$ decreasing with the operation temperature. This effect is probably caused by the electroreduction of the YSZ electrolyte. Our hypotheses are that YSZ reduction increases the oxygen electrode activity and reduces the overpotential. For high electrolyte reduction levels, electronic losses take place. Cell operation at severe electrolyte reduction conditions induces irreversible damage at the YSZ-LSM/YSZ interface as observed by SEM studies. Although these 
hypotheses are appealing and give an explanation for the experimental behaviour of these cells, they need to be confirmed by further experiments.

\section{Acknowledgments}

We would like to thank UKERC (NERC-TSEC programme grant number: NE/C516169/1), and grants MAT2009-14324-C02-01, GA-LC-009/2009 and CIT-120000-2007-50 financed by the Spanish Government, DGA-Caixa and Feder program of the European Community for funding the project. R. Campana and M. A. Laguna-Bercero would also like to thank IKERLAN-Energía and the JAE-program (CSIC) for financial support. Finally we thank Fausto Rubio (ICV-CSIC) for $\mathrm{Hg}$ porosimetry measurements and also IKERLAN-Energía and FEI Company for SEM experiments.

Table 1. Total porosity, open porosity and average pore diameter for the LSM/YSZ electrode.

\begin{tabular}{|c|c|c|c|}
\hline & $\begin{array}{c}\text { Functional layer } \\
\text { LSM50 }\end{array}$ & $\begin{array}{c}\text { Current } \\
\text { collector } \\
\text { LSM80 }\end{array}$ & $\begin{array}{c}\text { Ni/YSZ } \\
\text { support }\end{array}$ \\
\hline $\begin{array}{c}\text { Total porosity } \\
\text { (SEM } \\
\text { micrographs) }\end{array}$ & $\begin{array}{c}37.1 \% \text { (cell layer) } \\
27.3 \% \text { (pellet) }\end{array}$ & $\begin{array}{c}40 \% \text { (cell layer) } \\
28.2 \% \text { (pellet) }\end{array}$ & $38 \%$ (cell layer) \\
\hline $\begin{array}{c}\text { Open porosity } \\
\text { (Hg porosimetry) }\end{array}$ & $28.7 \%$ (pellet) & $31.3 \%$ (pellet) & $41.4 \%$ (cell layer) \\
\hline $\begin{array}{c}\text { Average pore } \\
\text { diameter } \\
\text { (Hg porosimetry) }\end{array}$ & $0.12 \mu \mathrm{m}$ & $0.15 \mu \mathrm{m}$ & $0.39 \mu \mathrm{m}$ \\
\hline
\end{tabular}

Table 2. Nernst potential and fitted parameters for the microtubular fuel electrode supported cell operated both in SOFC and SOEC mode at $950^{\circ} \mathrm{C}$ with $3 \%$ wet pure hydrogen and air.

\begin{tabular}{|c|c|c|}
\hline & FC & SOE \\
\hline $\mathbf{R}_{\mathbf{i}}\left(\mathbf{\Omega ~ c m}^{2}\right)$ & 0.35 & 0.7 \\
\hline $\mathbf{A}$ & 0.11 & 0.11 \\
\hline $\mathbf{B}$ & 0.015 & - \\
\hline $\mathbf{i}_{\text {as }}\left(\mathbf{A ~ c ~ ^ { - 2 }}\right)$ & 2 & 0.3 \\
\hline $\mathbf{E}_{\mathbf{0}}(\mathbf{V})$ & 1.10751 & 1.10751 \\
\hline
\end{tabular}

Table 3. Fuel utilization $\left(U_{\mathrm{f}}\right)$ and area-specific resistance (ASR) values obtained from the $j$-V curves at $750{ }^{\circ} \mathrm{C}$ in SOFC mode. 


\begin{tabular}{|c|c|c|c|c|c|}
\hline $\begin{array}{l}p \mathrm{H}_{2} \mathrm{O} \\
(\mathrm{atm})\end{array}$ & $\begin{array}{c}p \mathbf{H}_{2} \\
(\mathbf{a t m})\end{array}$ & $\begin{array}{c}j\left(\mathrm{~A} \mathrm{~cm}^{-2}\right) \\
\text { at } 0.65 \mathrm{~V}\end{array}$ & $\begin{array}{c}P\left(W \mathrm{~cm}^{-2}\right) \\
\text { at } 0.65 \mathrm{~V}\end{array}$ & $U_{\mathrm{f}}(\%)$ & $\operatorname{ASR}\left(\Omega \mathrm{cm}^{2}\right)$ \\
\hline 0.03 & 0.97 & 0.395 & 0.257 & 3.10 & $1.092 \pm 0.012$ \\
\hline 0.25 & 0.75 & 0.330 & 0.214 & 3.35 & $1.127 \pm 0.009$ \\
\hline 0.25 & 0.15 & 0.241 & 0.157 & 12.19 & $1.152 \pm 0.009$ \\
\hline 0.50 & 0.10 & 0.256 & 0.166 & 19.51 & $0.978 \pm 0.003$ \\
\hline
\end{tabular}

Table 4. SOEC mode. OCV Ohmic resistances $\left(\Omega \mathrm{cm}^{2}\right)$ measured by EIS and $R_{\mathrm{i}}$ values obtained from the slopes in the linear regions of the electrolysis $\mathrm{j}-\mathrm{V}$ curves for the different temperatures and gas compositions used.

\begin{tabular}{|c|c|c|c|c|c|c|}
\hline $\begin{array}{l}p \mathbf{H}_{2} \mathbf{0} \\
(\mathbf{a t m})\end{array}$ & $\begin{array}{c}p \mathbf{H}_{2} \\
(\mathbf{a t m})\end{array}$ & $750^{\circ} \mathrm{C}$ & $\begin{array}{c}820 \\
{ }^{\circ} \mathrm{C}\end{array}$ & $\begin{array}{c}895 \\
{ }^{\circ} \mathrm{C}\end{array}$ & $\begin{array}{c}950 \\
{ }^{\circ} \mathrm{C}\end{array}$ & \\
\hline 0.03 & 0.97 & - & - & - & $\begin{array}{c}0.12 \\
0.7\end{array}$ & $\begin{array}{c}\mathbf{R}_{\mathrm{ohm}}\left(\Omega \mathrm{cm}^{2}\right) \\
\mathbf{R}_{\mathrm{i}}\left(\Omega \mathrm{cm}^{2}\right)\end{array}$ \\
\hline 0.50 & 0.10 & $\begin{array}{c}0.26 \\
1.1\end{array}$ & $\begin{array}{c}0.21 \\
0.7\end{array}$ & $\begin{array}{c}0.15 \\
0.4\end{array}$ & $\begin{array}{c}0.14 \\
0.3\end{array}$ & $\begin{array}{c}\mathbf{R}_{\mathrm{ohm}}\left(\Omega \mathrm{cm}^{2}\right) \\
\mathbf{R}_{\mathrm{i}}\left(\Omega \mathrm{cm}^{2}\right)\end{array}$ \\
\hline 0.25 & 0.15 & $\begin{array}{c}0.31 \\
1.3\end{array}$ & $\begin{array}{l}0.27 \\
0.92\end{array}$ & $\begin{array}{c}0.21 \\
0.6\end{array}$ & $\begin{array}{l}0.20 \\
0.48\end{array}$ & $\begin{array}{c}\mathbf{R}_{\mathrm{ohm}}\left(\Omega \mathrm{cm}^{2}\right) \\
\mathbf{R}_{\mathrm{i}}\left(\Omega \mathrm{cm}^{2}\right)\end{array}$ \\
\hline
\end{tabular}

Figure Captions

Fig. 1 SEM micrograph (transverse cross-section) for the Ni/YSZ-YSZLSM/YSZ microtubular cell prior to operation. 
Fig. 2 Experimental $j$-V curves in both SOFC and SOEC modes measured at $950^{\circ} \mathrm{C}$ using humidified pure hydrogen as fuel, and their corresponding fitting by the use of Eq. 1 and Eq. 2 .

Fig. 3 SOFC experiments ( $j$-V curves) performed at $750{ }^{\circ} \mathrm{C}$ using different steam concentrations.

Fig. 4 Experimental $j$-V curves in both SOFC and SOEC modes measured at different temperatures with $\mathrm{AH}=50 \%$ (figure $4 \mathrm{a}$ ) and $\mathrm{AH}=25 \%$ (figure $4 b)$ as the fuel electrode.

Fig. 5 SEM micrograph (transverse cross-section) for the Ni/YSZ-YSZLSM/YSZ microtubular cell after operation.

\section{References}

${ }^{1}$ W. Donitz, R. Schmidberger, E. Steinheil, R. Steicher, Int. J. Hydrogen Energy 1980, 5, 55.

${ }^{2}$ E. W. Dönitz and E. Erdle, Int. J. Hydrogen Energy 1985, 10, 291.

${ }^{3}$ S.D. Ebbesen and M. Mogensen, J. Power Sourc. 2009, 193, 349.

${ }^{4}$ I. Chorkendorff and J. W. Niemantsverdriet, Concepts of Modern Catalysis and Kinetics, Wiley-VCH, Weinheim, 2006.

${ }^{5}$ W. Wang, J.M. Vohs and R.J. Gorte, Top. Catal. 2007, 46, 380.

${ }^{6}$ J. Martinez-Frias, A. Q. Pham and S. M. Aceves, Int. J. Hydrogen Energy 2003, 28, 483.

${ }^{7}$ A. Momma, J. Ceram. Soc. Japan 1997, 105, 369.

${ }^{8}$ H. Uchida, N. Osada, M. Watanabe, Electrochem. Solid State Lett. 2004, 7, A500.

${ }^{9}$ W. Wang, Y. Huang, S. Jung, J.M. Vohs, R.J. Gorte, J. Electrochem. Soc. 2006, 153, A2066.

${ }^{10}$ J. P. Ouweltjes, M. M. A. van Tuel, F. P. F. van Berkel, G. Rietveld, ECS Transactions, 2007, 7, 933.

${ }^{11}$ A. Hauch, S. H. Jensen, S. Ramousse and M. Mogensen, J. Electrochem. Soc. 2006, 153, A1741.

${ }^{12}$ High temperature solid oxide fuel cells: fundamentals, design, and applications, Subhash C. Singhal, Kevin Kendall, Elsevier, 2003

${ }^{13}$ O.A. Marina, L.R. Pederson, M.C. Williams, G.W. Coffey, K.D. Meinhardt, C.D. Nguyen, E.C.

Thomsen, J. Electrochem. Soc. 2007, 154, B452.

${ }^{14}$ B. Yu, W. Q. Zhang, J. M. Xu, and J. Chen, Int. J. Hydrogen Energy 2008, 33, 6873.

${ }^{15}$ M.A. Laguna-Bercero, J. A. Kilner, and S. J. Skinner, Solid State Ion. 2010, doi:10.1016/j.ssi.2010.01.003

${ }^{16}$ A. Hauch, S. D. Ebbesen, S. H. Jensen and M. Mogensen, J. Mater. Chem. 2008, 18, 2331.

${ }^{17}$ F. Chauveau, J. Mougin, J. M. Bassat, F. Mauvy, J. C. Grenier, J. Power Sources 2010, 195, 744.

${ }^{18}$ T. Suzuki, Z. Hasan, Y. Funahashi, T. Yamaguchi, Y. Fujishiro, M. Awano, Science 2009, 325, 852.

${ }^{19}$ K. W. Galloway, N. M. Sammes, J. Electrochem. Soc. 2009, 156, B526

${ }^{20}$ V. Lawlor, S. Griesser, G. Buchinger, A.G. Olabi, S. Cordiner, D. Meissner, J. Power Sources 2009, 193, 387.

${ }^{21}$ K. Kendall, Int. Appl. Ceram. Technol. 2010, 7, 1-9.

${ }^{22}$ J. Pusz, A. Mohammadi, N. M. Sammes, J. Fuel Cell Sci. Tech. 2006, $3,482$.

${ }^{23}$ J. Ding, J. Liu, J. Am. Ceram. Soc. 2008, 91, 3303.

${ }^{24}$ S. D. Kim, S. H. Hyun, J. Moon, J. H. Kim, R. H. Song, J. Power Sourc. 2005, 139, 67.

${ }^{25}$ R. N. Basu, G. Blass, H. P. Buchkremer, D. Stöver, F. Tietz, E. Wessel, I. C. Vinke, J. Am. Ceram. Soc. 2005, 25, 463.

${ }_{26}$ M. A. Laguna-Bercero, R. Campana, A. Larrea, J. A. Kilner and V.M. Orera, J. Electrochem. Soc. 2010, 6, B852. 
${ }^{27}$ R. L. LeRoy, C. T. Bowen, D. J. LeRoy, J. Electrochem. Soc. 1980, 127, 1954.

${ }^{28}$ J. Schefold, A. Brisse and M. Zahid, J. Electrochem. Soc. 2009, 156, B897.

${ }^{29}$ R. Campana, R. I. Merino, A. Larrea, I. Villarreal, V. M. Orera, J. Power Sourc. 2009, 192, 120.

${ }^{30}$ M. A. Laguna-Bercero, J. A. Kilner and S. J. Skinner, Chem. Mater. 2010, 22, 1134.

${ }^{31}$ R. Campana, A. Larrea, R. I. Merino, I. Villarreal, V. M. Orera, Bol. Soc. Esp. Ceram. V. 2008, 47, 189.

${ }^{32}$ A. Brisse, J. Schefold and M. Zahid, Int, J. Hydrogen Energy 2008, 33, 5375.

${ }^{33}$ J-W. Kim, A.V. Virkar, K-Z. Fung, K. Mehta and S.C. Singhal, J. Electrochem. Soc. 1999, 146, 69.

${ }^{34}$ A. Doddathimmaiah and J. Andrews, Int. J. Hydrog. Energy 2009, 34, 8157.

${ }^{35}$ M. F. Serincan, U. Pasaogullari, N. M. Sammes, J. Power Sourc. 2009, 192, 414.

${ }^{36}$ W. Weppner, J. Electroanal. Chem. 1997, 84, 339.

${ }^{37}$ D. A. Wright, J. S. Thorp, A. Aypar, H. P. Buckley, J. Mat. Sci. 1973, 8, 876.

${ }^{38}$ R. I. Merino, V. M. Orera, E. E. Lomonova and S. Kh Batygov, Phys Rev. 1995, 52, 6150.

${ }^{39}$ V. M. Orera, R. I. Merino, Y. Chen, R. Cases and P.J. Alonso, Phys Rev. 1990, 42, 9782.

${ }^{40}$ R. I. Merino and V.M. Orera, Solid State Ionics 1995, 76, 97.

${ }^{41}$ H. Uchida, N. Osada and M. Watanabe, Electrochem. Solid-State Lett. 2004, 7, A500.

${ }^{42}$ M. Gödickemeier and L. J. Gauckler, J. Electrochem. Soc. 1998, 145, 414.

${ }^{43}$ I. Riess, M. Gödickemeier and L.J. Gauckler, Solid State Ion. 1996, 90, 91.

${ }^{44}$ S. Wang, T. Kato, S. Nagata, T. Kaneko, N. Iwashita, T. Honda and M. Dokiya, Solid State Ion. 2002, $152,477$. 